\title{
The Meaning of Typographic Design in Malang Urban Space: Based on Signs and Objects Relations
}

\author{
Indyah Martiningrum*
}

\begin{abstract}
Department of Architecture, Faculty of Engineering, Universitas Brawijaya, Malang, Indonesia. *Corresponding author. Email: indyahmartiningrum@gmail.com
\end{abstract}

\begin{abstract}
The phenomenon of the big text signs in almost all cities in Indonesia to mark the name of a place that is already known by the surrounding community will ultimately affect the collective knowledge of citizens. It is just that the presence of big writing is no longer unique when all the cities are busy creating and becoming stereotypes. However, without any endemic uniqueness that can be highlighted and proud of, the city's sense of place becomes a cliche. Its presence has plagued like a disease and become a talkative phenomenon for urbanites in Indonesia, Malang City is no exception. This study aims to interpret the phenomenon of urban space typography design in semiotics based on the pragmatic paradigm through the second semiosis process of the relation between representamen (signs) and objects in the city of Malang. The selected objects are typography of Malang City Square, Batu City Square, Idjen Boulevard, Brawijaya University, and Malang State University. This study uses a descriptive mix-method approach in exploring the meaning of the audience and understanding interpretants of the phenomenon of a series of uppercase letters in the urban space. The study shows that there is a relationship between the representamen (signs) and objects as icons and indexes. Nevertheless, it has not yet reached the relationship as symbols.

Keywords: Typography, pragmatics, semiosis II, representamen, object, sign
\end{abstract}

\section{INTRODUCTION}

At present, there is a phenomenon of big signs (large text) in most cities in Indonesia to mark the name of a place that is already known by the surrounding community. What happens is the relationship between kinetic and verbal nature simultaneously [1].

In some corners of the city and certain other places, even on the campus, many public spaces are plastered with big signboard. This trend was started by one city, then spread and infect other cities. Apart from economic-political intrigue, one of which became a kind of project for the procurement of goods and services, this trend is an indication that there has been an event of extraction from one urban institution followed by many other urban institutions for no apparent reason [2]. The mimetic process represents talkative behavior. Latah usually happens personally, but with the symptoms above, it turns out that talkative is not only in verbal-personal form but also can massively touch urban-institutional [3]. In the talkative, both personal and institutional interests follow a trend without knowing why to do it. It seems like urban behavior that moves distortively.

Letters arranged into large typography are intended to provide information and/ or elements of urban sculptures. The series of letters is present as a linguistic which can be partly a part of communication theory or significance. The term communication usually refers to the use and influence of a sign system. Meanwhile, the term signification refers to the properties, internal relations, and rules that control the sign system.

From the point of view of pragmatism (Peirce), signs that are factually present are forms of reality and can build meaning. The process of forming meaning involves three elements, namely: the first symptom, in which quality can or may appear as a sign; the second symptom means the sign actually (here and now); the third symptom when the sign has become a generally accepted fact in society (consensus). Among these three symptoms, the process of forming meaning (semiosis) occurs in two poles, namely semiosis at the interpretant pole and semiosis at the representamen (sign)-object pole. The first semiosis is commonly referred to as the process of forming interpretants, which involves habit, belief, doubt, and a series of abduction-deduction-induction. Meanwhile, the second semiosis is often referred to as the exploration of relations between the two triadic elements, namely between the sign-object (dyadic) in the constellation of interpretant-sign-object (triadic). Between the two processes of semiosis can be studied separately.

Peirce represents the initial concept of modern semiotics, with a triadic tradition. Peirce can be seen as a representative of American Semiotics with a pragmatic background (behaviorist and positivist), [and Saussure can be seen as a representative of rationalist and structuralist Continental Semiotics]. One of the relations of discussion in semiotics is the theory of meaning. In Peirce's (and Saussure) semiotics, discussion of meaning cannot be done directly except by first explaining their concept of signs, 
which includes the concept of sign systems, sign categories, and sign organizations.

At Barthes, the discussion of meaning can be done more clearly because Barthes does specifically discuss the dimensions of meaning as a process of negotiation between the writer/reader and the text. Roland Barthes covered Saussure's shortcomings by paying more attention to the interaction of signs in the text with the personal and cultural experience of the wearer.

Knowledge in the second stage of semiosis is indirect knowledge through signs [4]. Knowledge is not obtained directly from objects or realities (discontinuous lines). Signs are typologies according to relations between the two elements (Figure 1).

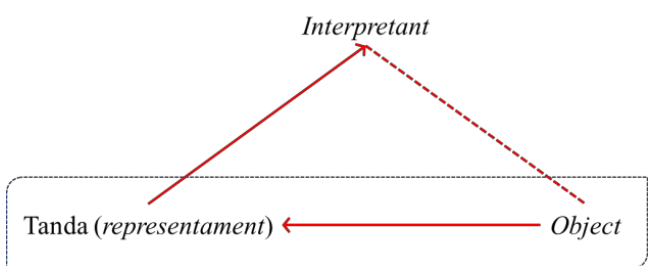

Figure 1 Semiosis stage 2 (modified from Noerhadi [4])

\section{RESEARCH METHOD}

This study uses a descriptive mix-method approach in exploring the meaning of the audience and understanding interpretants of the phenomenon of a series of uppercase letters in urban space. Qualitative method is needed to explore the ideas of citizens through field observations in the mode of open questions. The quantitative method is needed when the exploration results are codified in such a way as to compile and get the core of the questionnaire in open question mode. The descriptive method is used to describe the background details or contextuality of the audience to the urban environment that has been penetrated by the phenomenon of environmental typography [5].

This study involved respondents in a purposive field observation and survey respondents randomly to approach the requirements for the number of samples required in the population. The results of the analysis are interpreted and verified (the discussion stage) through Peirce's theoretical references simultaneously. The interpretation also carried out cross-references with other sources. All interpretations are still within the framework of understanding the meaning of the second phase of semiosis, which always involves the relation of representamen and objects.

\section{RESULT AND DISCUSSION}

\subsection{Overview of Research Objects and Respondents}

The object of this research is in the Greater Malang area, the position of the urban typography is in the node element of the city (node) represented by Malang City Square and Batu City Square. The path element is represented by Jalan Ijen, while the regional element is represented by the Universitas Brawijaya Campus and the Malang State University Campus

Respondents numbered 278 people who entered and responded to the questionnaire submitted via digital media, consisting of $43.6 \%$ men and $53.4 \%$ women. The age of respondents is in the age range $<16$ to $>46$ years old, with the predominance of respondents in the age group 17-25 years old $(85.79 \%)$. The age range of the majority of respondents shows that it is relatively homogeneous with a fairly mature age so that it can be expected that the visual appearance of the sign (representamen) from each other does not differ much.

\subsection{Analysis}

The analysis is done by identifying the relationship between the representamen and the object. Each representamen and objects are identified at the level firstness, secondness, and thirdness.

a. Typography "Idjen Boulevard": The results of identifying relations between representamen and objects in the typography "Idjen Boulevard" through the simultaneous analysis of the content of the questionnaire showed the closeness of existence between the sign and the object. Typography is also considered to be related to the name of the region.

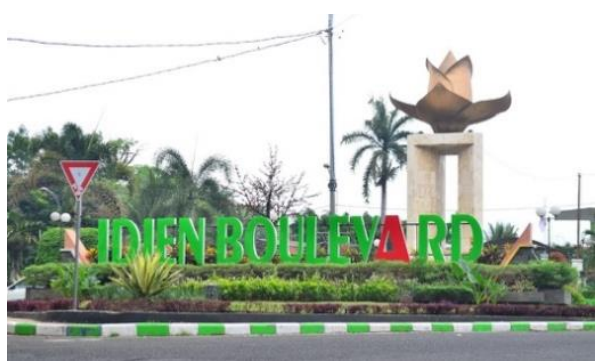

Figure 1 Typography "Idjen Boulevard" 
Table 1 Identification of relations between representamen and objects in the typography "Idjen Boulevard"

\begin{tabular}{|c|c|c|}
\hline $\begin{array}{c}\text { Category / } \\
\text { Trichotomy }\end{array}$ & Representamen & Object \\
\hline $\begin{array}{l}\text { Firstness } \\
\text { Autonomous }\end{array}$ & $\begin{array}{l}\text { Qualisign: } \\
\text { The green color that dominates the arrangement of letters } \\
\text { refers to the beauty of the park. There is a red accent on } \\
\text { letter A and at the beginning and end of a series of letters. }\end{array}$ & $\begin{array}{l}\text { Icon: } \\
\text { There is no similarity between the written form and aspects } \\
\text { related to the nature of the location. }\end{array}$ \\
\hline $\begin{array}{l}\text { Secondness } \\
\text { Connected with } \\
\text { reality. }\end{array}$ & $\begin{array}{l}\text { Sinsigns: } \\
\text { The inscription 'Idjen" with the old spelling shows the } \\
\text { historical aspects of the Dutch colonial heritage area. }\end{array}$ & $\begin{array}{l}\text { Index: } \\
\text { The existence of closeness between the sign with the object. } \\
\text { Typography is related to the name of the region }\end{array}$ \\
\hline $\begin{array}{l}\text { Thirdness } \\
\text { Linked to rules, } \\
\text { conventions, or } \\
\text { codes. }\end{array}$ & $\begin{array}{l}\text { Legisigns: } \\
\text { The green color used is similar to the color of the Malang } \\
\text { City logo. Green is considered to represent fertility. }\end{array}$ & $\begin{array}{l}\text { Symbol: } \\
\text { The conventional relationship is shown by the green color } \\
\text { used following the color of the Malang City logo. The form } \\
\text { and appearance are not enough to be a symbol. }\end{array}$ \\
\hline
\end{tabular}

b. Typography "Universitas Brawijaya": The results of the questionnaire analysis showed that most visitors stated that this object is known by them strongly through the relationship between the text and place. The place, in this case, is related to the institution.

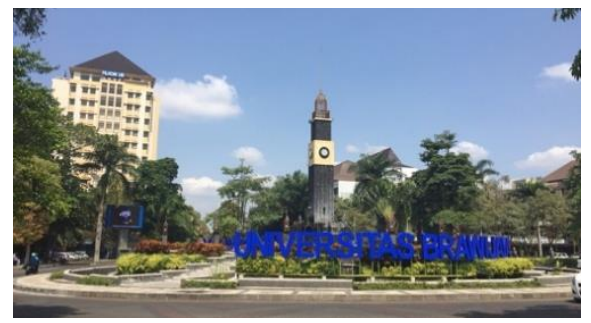

Figure 2 Typography "Universitas Brawijaya"

Table 2 Identification of relations between representamen and objects in the typography "Universitas Brawijaya"

\begin{tabular}{|c|c|c|}
\hline $\begin{array}{c}\text { Category / } \\
\text { Trichotomy } \\
\end{array}$ & Representamen & Object \\
\hline $\begin{array}{l}\text { Firstness } \\
\text { Autonomous }\end{array}$ & $\begin{array}{l}\text { Qualisign: } \\
\text { The blue color dominates the arrangement of letters of } \\
\text { the same size. The typeface is very familiar. }\end{array}$ & $\begin{array}{l}\text { Icon: } \\
\text { There is no similarity between the written form and aspects } \\
\text { related to the nature of the location. Typographic position } \\
\text { around the clock monument. }\end{array}$ \\
\hline $\begin{array}{l}\text { Secondness } \\
\text { Connected with } \\
\text { reality. }\end{array}$ & $\begin{array}{l}\text { Sinsigns: } \\
\text { The words "Universitas Brawijaya" are strategically } \\
\text { positioned in front of the Rector's building }\end{array}$ & $\begin{array}{l}\text { Index: } \\
\text { The existence of closeness between the sign and the object. } \\
\text { Typography is related to the name of the institution. }\end{array}$ \\
\hline $\begin{array}{l}\text { Thirdness } \\
\text { Linked to rules, } \\
\text { conventions, or } \\
\text { codes. }\end{array}$ & $\begin{array}{l}\text { Legisigns: } \\
\text { The blue color used is following the color of UB's alma } \\
\text { mater jacket }\end{array}$ & $\begin{array}{l}\text { Symbol: } \\
\text { The conventional relationship is shown by the blue color, } \\
\text { which is identical to the color of UB. The form and } \\
\text { appearance are not enough to be a symbol. }\end{array}$ \\
\hline
\end{tabular}

c. Typography "Alun-Alun Kota Wisata Batu": The results of the questionnaire analysis showed that most visitors stated that this typography is strongly related and refers to Batu City as the leading tourist city in East Java.

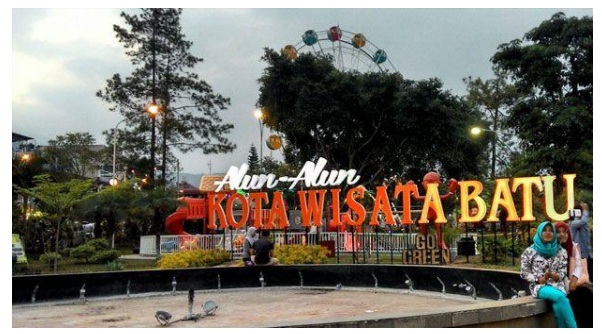

Figure 3 Typography "Alun-Alun Kota Wisata Batu"

Table 3 Identification of relations between representamen and objects in the typography "Alun-Alun Kota Wisata Batu "

\begin{tabular}{|c|c|c|}
\hline $\begin{array}{c}\text { Category / } \\
\text { Trichotomy }\end{array}$ & Representamen & Object \\
\hline $\begin{array}{l}\text { Firstness } \\
\text { Autonomous }\end{array}$ & $\begin{array}{l}\text { Qualisign: } \\
\text { There are different types of letters and colors, in the } \\
\text { word "Alun-Alun" and the series of words "Batu Wisata } \\
\text { City". It shows the emphasis on the location aspect of } \\
\text { Batu City as a tourist city. }\end{array}$ & $\begin{array}{l}\text { Icon: } \\
\text { There is no similarity between the written form and aspects } \\
\text { related to the nature of the location. }\end{array}$ \\
\hline
\end{tabular}




\begin{tabular}{|l|l|l|}
\hline \multicolumn{1}{|c|}{$\begin{array}{c}\text { Category / } \\
\text { Trichotomy }\end{array}$} & \multicolumn{1}{c|}{ Representamen } & \multicolumn{1}{c|}{ Object } \\
\hline $\begin{array}{l}\text { Secondness } \\
\text { Connected with } \\
\text { reality. }\end{array}$ & $\begin{array}{l}\text { Sinsigns: } \\
\text { The typographic position is in the area of the square. } \\
\text { Festive colors and artificial lighting effects at night } \\
\text { become an attraction for visitors to move around the } \\
\text { square }\end{array}$ & $\begin{array}{l}\text { Index: } \\
\text { The existence of closeness between the sign with the object. } \\
\text { Typography is related or refers to Batu City as the leading } \\
\text { tourist city in East Java. }\end{array}$ \\
\hline $\begin{array}{l}\text { Thirdness } \\
\begin{array}{l}\text { Linked to rules, } \\
\text { conventions, or } \\
\text { codes. }\end{array}\end{array}$ & $\begin{array}{l}\text { Legisigns: } \\
\text { The selected font is not the same as the font used by the } \\
\text { Batu Kota Wisata logo. Not related to certain } \\
\text { conventions. }\end{array}$ & $\begin{array}{l}\text { Symbol: } \\
\text { Conventional relationships are not identified. The shape and } \\
\text { appearance are not enough to be a symbol. }\end{array}$ \\
\hline
\end{tabular}

d. Typography "Alun-Alun Malang": The results of the questionnaire analysis showed that most visitors stated that this object is known by them through the strong relationship between the text and place.

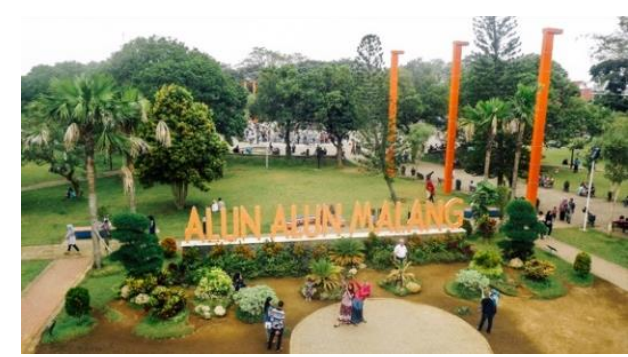

Figure 4 Typography "Alun-Alun Malang"

Table 4. Identification of relations between representamen and objects in the typography "Alun-Alun Malang "

\begin{tabular}{|c|c|c|}
\hline $\begin{array}{l}\text { Category / } \\
\text { Trichotomy }\end{array}$ & Representamen & Object \\
\hline $\begin{array}{l}\text { Firstness } \\
\text { Autonomous }\end{array}$ & $\begin{array}{l}\text { Qualisign: } \\
\text { Typography "Malang Square" has a bright orange color, } \\
\text { contrasting with the background of green vegetation in } \\
\text { the landscape. }\end{array}$ & $\begin{array}{l}\text { Icon: } \\
\text { There is no similarity between the written form and aspects } \\
\text { related to the nature of the location. }\end{array}$ \\
\hline $\begin{array}{l}\text { Secondness } \\
\text { Connected with } \\
\text { reality. }\end{array}$ & $\begin{array}{l}\text { Sinsigns: } \\
\text { The typographic position is in the area of the square- } \\
\text { the position is in the middle of the main attraction of } \\
\text { visitors to move around the big sign. }\end{array}$ & $\begin{array}{l}\text { Index: } \\
\text { The existence of closeness between the sign with the object. } \\
\text { Typography related or refers to the city of Malang. }\end{array}$ \\
\hline $\begin{array}{l}\text { Thirdness } \\
\text { Linked to rules, } \\
\text { conventions, or } \\
\text { codes. }\end{array}$ & $\begin{array}{l}\text { Legisigns: } \\
\text { The typeface (font) is not the same as the font used by } \\
\text { the symbol "Malang City". Not related to certain } \\
\text { conventions. }\end{array}$ & $\begin{array}{l}\text { Symbol: } \\
\text { Conventional relationships are not identified. The shape and } \\
\text { appearance are not enough to be a symbol. }\end{array}$ \\
\hline
\end{tabular}

e. Typography "UM"(Universitas Negeri Malang): The results of the questionnaire analysis showed that most visitors stated that this typography had a similarity with the official symbol of the State University of Malang, which was indicated by the similarity of the letters.

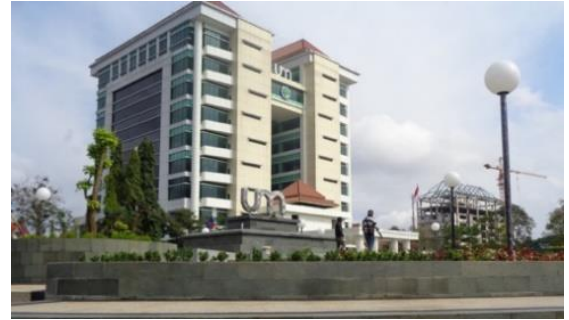

Figure 5 Typography "UM"

Table 5 Identification of relations between representamen and objects in the typography "UM "

\begin{tabular}{|l|l|l|}
\hline \multicolumn{1}{|c|}{$\begin{array}{c}\text { Category / } \\
\text { Trichotomy }\end{array}$} & \multicolumn{1}{c|}{ Representamen } \\
\hline $\begin{array}{l}\text { Firstness } \\
\text { Autonomous }\end{array}$ & $\begin{array}{l}\text { Qualisign: } \\
\text { The impression of color that is captured visually is } \\
\text { caused by the type of material applied, which is a kind } \\
\text { of metal layer that reflects light. The selected font has a } \\
\text { unique design. }\end{array}$ & $\begin{array}{l}\text { Icon: } \\
\text { The similarity between the typography and the official symbol } \\
\text { of Malang State University is shown by the similarity of the } \\
\text { letters. }\end{array}$ \\
\hline $\begin{array}{l}\text { Secondness } \\
\begin{array}{l}\text { Connected with } \\
\text { reality. }\end{array}\end{array}$ & $\begin{array}{l}\text { Sinsigns: } \\
\text { The written form "UM" refers to Malang State } \\
\text { University as an educational institution. }\end{array}$ & $\begin{array}{l}\text { Index: } \\
\text { The existence of closeness between the sign with the object. } \\
\text { Typography is related to the name of the institution. }\end{array}$ \\
\hline
\end{tabular}




\begin{tabular}{|l|l|l|}
\hline \multicolumn{1}{|c|}{$\begin{array}{c}\text { Category / } \\
\text { Trichotomy }\end{array}$} & \multicolumn{1}{c|}{ Representamen } & \multicolumn{1}{c|}{ Object } \\
\hline $\begin{array}{l}\text { Thirdness } \\
\text { Linked to rules, } \\
\text { conventions, or } \\
\text { codes. }\end{array}$ & $\begin{array}{l}\text { Legisigns: } \\
\text { The UM typographic form is the latest logo introduced } \\
\text { by Malang State University as an institution's symbol. }\end{array}$ & $\begin{array}{l}\text { Symbol: } \\
\text { Conventional relationships are shown as UM symbols, but } \\
\text { representamen is not enough to be a symbol. }\end{array}$ \\
\hline
\end{tabular}

f. Summary of the Process of Semiosis Exploration of Representamen and Object Relations: Based on tracking the types of representamen and their relationships as objects by referring to the levels of firstness, secondness, and thirdness, it can be concluded that the relation is as follows:

Table 6 Summary of representamen to object relations

\begin{tabular}{|l|l|c|c|c|}
\hline \multirow{2}{*}{ No. } & \multirow{2}{*}{ Representamen } & \multicolumn{3}{|c|}{ Category / Trichotomy } \\
\cline { 3 - 5 } & & Firstness: Qualisigns & Secondness: Sinsigns & Thirdness: Legisigns \\
\cline { 3 - 5 } & Icon & Index & Symbol \\
\hline 1. & Idjen Boulevard & & $\checkmark$ & \\
\hline 2. & Universitas Brawijaya & & $\checkmark$ & \\
\hline 3. & $\begin{array}{l}\text { Alun-Alun Kota Wisata } \\
\text { Batu }\end{array}$ & & $\checkmark$ & \\
\hline 4. & Alun-Alun Malang & & & \\
\hline 5. & UM & $\checkmark$ & & \\
\hline
\end{tabular}

\section{CONCLUSION}

Based on the results of the study, the four observed objects in this study, the big sign typography of "Idjen Boulevard", "Universitas Brawijaya", "Batu Tourism City Square", and "Malang Square" can meet the indicators of the sinsigns category that indicate a connection sign on the basis of appearing in reality or the actual existence of objects or events that exist on the sign. This power refers to a sign that is designed to indicate a source of reference or to interconnect reference sources. There is a sign/ representative relationship and its reference based on existential closeness, namely the location and the name of the institution. Thus, the first four sequences of big sign typography are valid as an index. Then one last big sign typography, "UM," shows strength in the category of qualisigns. There is a unique form that some respondents consider to have artistic value. The sign relates to the object because there is a similarity in shape to the UM symbol so that it acts as an icon of the institution.

\section{ACKNOWLEDGMENT}

The author would like to thank Research and Community Service Board of the Faculty of Engineering Universitas Brawijaya (BPPM FTUB) for the financial support of this research; to Mr. Susilo Kusdiwanggo and Mr. Chairil B. Amiuza for contributing the knowledge of semiotics and the research sharing.

\section{REFERENCES}

[1] Vinegar, A, I am a Monument on Learning from Las Vegas, Cambridge: The MIT Press, 2008.

[2] Robert Venturi, D. S., Learning from Las Vegas: The Forgotten Symbolism of Architetural Form, Urban Life, 192 (1979).

[3] Liwang, F., Latah: Penyakit, Kebiasaan, atau Budaya? Kompasiana, Jakarta, 24 June 2015.

[4] Noerhadi, T. H., Semiotika dan Filsafat, Dalam R. S. EKM Masinambow, Semiotik (hal. 1-9). Depok: PPKB Lemlit UI, 2000.

[5] Chris Calori, D. V.-E, A Complete Guide to Creating Environmental Graphic Design Systems: Signage and Wayfinding Design (Second ed.), New Jersey: John Wiley \& Sons, Inc, 2015. 